\title{
Private Sector Participation in Infrastructure Development: A Non- Resident Infrastructure Fund in Bangladesh
}

\author{
Md. Mahmudul Alam* \\ PhD Student \\ Institute for Environment and Development (LESTARI) \\ National University of Malaysia (UKM) \\ Selangor, Malaysia \\ E-mail: rony000@gmail.com
}

\begin{abstract}
Md. Abu Rashed
Senior Consultant, Project Development

Infrastructure Investment Facilitation Center (IIFC)

An enterprise of Economic Relations Division (ERD)

Ministry of Finance, Government of Bangladesh

Dhaka, Bangladesh

E-mail: arashed@infra-bd.com
\end{abstract}

*corresponding author

\section{Citation Reference:}

Alam, M.M., and Rashed, M.A. 2011. Private Sector Participation in Infrastructure Development: A Non-Resident Infrastructure Fund in Bangladesh, Journal of Bangladesh Studies, Vol. 13(1), pp. 34-38. Available at < https://drive.google.com/drive/folders/0B UFhxFWMtkXSzdQVUNUbFY1X3c >

This is a pre-publication copy.

The published article is copyrighted by the publisher of the journal. 


\title{
Private Sector Participation in Infrastructure Development: A Non- Resident Infrastructure Fund in Bangladesh
}

\begin{abstract}
Infrastructure is considered as the engine of growth for an economy with possibilities of high return for the investors. However, in Bangladesh the infrastructure sector has been suffering a lot due to fund shortage. Bangladesh is one of the highest remittance recipient countries in the world, but the current saving schemes of the country are not enough to attract the non-resident Bangladeshis (NRB). In this situation, an NRB Infrastructure Fund (NIF) can be established, where NRBs will invest in private infrastructure projects like toll roads, private power plant, land and seaport etc. In 2004, the Government prepared the Private Sector Infrastructure Guidelines (PSIG) that emphasized formation of NRB funds for infrastructure sectors. Except for three general mutual funds for NRB under Investment Corporation of Bangladesh (ICB), there has been no other initiative. The viability of the fund remains far below the expectations. This paper proposes an NRB fund for private infrastructure development with option to trade the shares in the local market. The fund will be used for a longer period of time in the company in compliance with the infrastructure project parameters. The paper also provides some technical and commercial proposals for forming such a fund in the country and examines its impacts on the economy as a whole.
\end{abstract}

Key Words: Infrastructure Development; Remittance; Migration, Non-residence Bangladeshi (NRB); Infrastructure Development Fund; Bangladesh

\subsection{Introduction}

Bangladesh is considered as one of the major labor exporting countries of the world. In Bangladesh, the total number of migrants, officially, was 4.55 million from 1976 to 2006. This is approximately $3.5 \%$ of the total population who send remittances to Bangladesh. A Bangladeshi living outside the country for six months is termed as Non-Resident Bangladeshi (NRB). According to Siddiqui (2003), some 200,000 or more Bangladeshis leave the country officially every year to work elsewhere. It also reveals that more than 1 million Bangladeshis live outside the country permanently, reflecting the extent of emigration. Most of these migrants send part of their earnings to home on a regular or irregular basis.

Remittances are the foreign currencies that migrants send to their home country. These NRBs sent remittances amounting to \$1.4 billion in the year of 2005-2006 (Bangladesh Bank, 2006), which helped to place Bangladesh at the $14^{\text {th }}$ position among top remittance recipient countries of the world. The growth rate of remittance inflow of Bangladesh is also very high which was $23 \%$ in 2006 (The Daily Star, 2006). According to Berlage et al. (2003), who have compiled data from a number of information sources, Bangladesh was the sixth remittance receiving country in 1999 in the world in absolute figure. In 2009, the remittance growth rate was $20 \%$ though migrant workers decreased by $46 \%$ from 2008 to 2009. In 2009, remittance inflow reached to $\$ 10.7$ billion (The Daily Star, 2010).

The Government of Bangladesh offers various savings instruments for the NRBs to attract remittances such as Non-Resident Foreign Currency Deposit (NFCD) ${ }^{1}$, US Dollar Premium Bond ${ }^{2}$, Wage earners development Bond ${ }^{3}$ etc. Furthermore, Non-resident Bangladeshi investors enjoy facilities similar to those of foreign investors. For foreign direct investment, there is no limitation pertaining to foreign equity participation, i.e. 100 percent foreign equity is allowed. Non-resident institutional or individual investors also can make portfolio investments in stock exchanges in Bangladesh. Moreover, there is also a reserved 
quota for NRBs in case of newly issued shares/debentures (IPO) of Bangladeshi companies. Government of Bangladesh has also decided to select 50 Important Non-Resident Bangladeshi (INRB) to honor them, such as providing extra privileges, treated as VIP, awarding certificate, providing public reorganization, etc., for contributing to the national economy based on some criteria like investment up to USD $\$ 0.50$ million in industrial sector or remittances of USD $\$ 750,000$ through proper banking channel.

In spite of such initiatives, sufficient investment from NRB has not yet been observed. A previous study (INAFI, 2004) showed that $80 \%$ of the remittance is used in non-productive expenditure. It indicates that the current saving scheme, industrial environment, investment opportunity, scope of lucrative and long term return are not enough to attract the NRBs. To provide a better investment opportunity for NRBs as well as to develop the infrastructure sector of Bangladesh through private investment, government has taken a wide-range of liberalization initiatives and prepared the Bangladesh Private Sector Infrastructure Guideline (BPSIG). The Guidelines mention the private investor, a single or a consortium of few investors, especially NRBs - "The Government shall encourage an infrastructure development fund or funds in which non-resident Bangladeshis may invest in developing Private Infrastructure Projects" (BPSIG, 2004). The government has recently provided great emphasis on boosting up private sector infrastructure projects (which are commonly known as Public-private Partnership (PPP) projects) in the country. Special attention has been put forward to transport, power, health, and education sectors. The present government has adopted, for the first time, a PPP budget for fiscal year 2009-2010 which is parallel to the traditional development and revenue budget. The budget has provision for technical assistance to develop new PPP projects in the country with a view to open up new opportunity for private sector investment. This will enable wider scope for NRBs to find more suitable PPP projects to invest.

But until now the government has not been able to take enough initiative to develop a NRB infrastructure fund in Bangladesh, except for three general mutual funds for NRBs operated by Investment Corporation of Bangladesh. Total current value of three funds stands at an approximate value of USD \$40 million up to June 2010 (DSE, 2010). These NRB mutual funds are as like as a normal mutual fund in the stock exchange, that maintain a portfolio consisting of the share and bonds of any types of company and only involving in investment rather than engaging any operational or production activities. This paper suggests a model for the NRB fund for infrastructure development with critical examination of its necessity for the country. This proposed fund is exclusively focusing on the private infrastructure related projects or Public-Private Partnership (PPP) projects. Moreover, this fund will consider maintenance of a project portfolio including the share and bond of other existing infrastructure projects.

\subsection{The Economic Role of NRB Funds}

According to a recent study on the investment in infrastructure needed in Bangladesh to achieve the Millennium Development Goal (MDG), an amount of USD \$85 billion would be required in just four sectors: power, water and sanitation, roads and telecom. This amount would exceed USD $\$ 100$ billion if other sectors of infrastructure are considered. The total investment in the currently pipelined private infrastructure projects is approximately USD $\$ 3,639$ million. An NRB Infrastructure Fund is expected to bridge the deficiency of fund. The initial size of the NRB Infrastructure Fund could be in the range of USD \$7-15 million. 
At the same time, the experiences of PPP projects in Bangladesh are very good. In the country, at least 35 PPP projects have been operational in power, land port, optic fiber, PSTN etc. The rate of return of these projects generally vary from $15-30 \%$ (as evidenced from Expected IRR is the tenders submitted and subsequent reflection in the concession agreement signed and Annual report of the SPVs). More than $80 \%$ of the PPP projects that have gone to tendering have been implemented in Bangladesh. Except few of them (3 land ports particularly), almost all other projects have been earning more than the projected IRR (as evident from the royalty they have been providing to Executing Agencies, otherwise there would be court cases as this are fixed in the concession agreement). And none of the PPP projects has been calculated less than 15\% IRR as per the tender submitted. This refers that NRB infra-fund is not riskier. A numbers of PPP projects (especially under IPFF) have been financed by IIDFC, IDCOL, IDLC, and few other financial institutions (mostly with bank syndication). Now, the basic is for large PPPs, the existing PPP financing facilities is not sufficient. IPFF and IDCOL have come forward for finance some of them. The result showed outstanding achievement (for IPFF of the World Bank with USD 57m, the planned four year project has been completed disbursing all the amount even in two years) which brings the necessity of alternative financing vehicles like the proposed NRB fund. This brings a good potential market for the proposed fund.

Regarding the financing of PPP projects, the loan repayment period ranges from 10 to 25 years (IPFF provides for 20 years while PPIDF of IDCOL also provides for more than 15 years). But the most available and popular deposit schemes of commercial banks are shorter term, mostly at highest for 5 years. So, the existing financial institutions (apart from that of IPFF and IDCOL) of Bangladesh are rarely willing to provide long-term loan facility in any project. As a result, investors of infrastructure projects suffer immensely from lack of fund. To address this difficulty, an infrastructure fund could be formed, which will provide investors with long-term financing facility.

Every year huge amount of remittance comes in Bangladesh through unofficial channels. According to World Bank's survey of households, the informal sources of remittance channel are still higher than that of formal channel (formal $46 \%$ and informal $54 \%$ ) (World Bank, 2006). Studies show that $40 \%$ of total remittances are sourced through the illegal hundi business, $46 \%$ through official source, and some $4.61 \%$ is coursed through friends and relatives, and $8 \%$ by migrant workers when they come home (The Daily Star, 2004).

In 2004, the central bank with the government has adopted strict measures to prevent unofficial channels of foreign exchange transfer. The Bangladesh Bank continues its efforts to encourage NRBs to send their money through official channels. Although the flow of remittance through official channels is increasing, changed economic policies in some emigration countries encouraged migrants to send more remittances to their home. Moreover, the remittance inflow has been increased due to newly introduced easier and cheaper processes for sending remittance (The Daily Star, 2002). Earlier the Nationalized Commercial Banks (NCBs) were the main official channels to transfer remittance. The NCBs have some overseas branches in the United States, Europe and Middle East. But the process of transferring remittance through NCBs is lengthy and takes some days. Therefore, private commercial banks (PCBs) have come forward with remittance business providing quick and reliable services and attracting the Bangladeshi wage earners to send money home through banking channel. Moreover, recent financial crisis and meltdown of many banks around the 
world influences NRBs to consider home country as a safer place for savings. That is another reason to increase remittance inflow since 2009.

Normally investment in stock market and industrial sector is very risky for nonresident individuals who have no previous experience in these sectors and stay in a long distance. As a result, their real opportunity for investment is too little to influence them to save and invest more in home country. So, at present, if proper initiative can be taken, annual NRB investment would be more than US \$1 billion in Bangladesh.

\subsection{Formation and Operation of the Fund}

The proposed infrastructure fund is planned to be created by pooling money from NRBs. This fund may be formed as a trust and also as a public limited company. The stakeholders of the fund will be sponsors, trustee, company, and private investors - NRBs.

3.1 The Model of NRB Fund: The fund is to be initiated by some sponsors. Sponsors will create a trust in paper by a trust deed with some renowned personalities in the Board of Trustees. For an example, initially the chairman of Board of Investment (BOI) or any renowned local person or NRB can chair the board of trustees. The sponsors will apply to the local registration office to register it as a trust. After the registration, the trustees will open a special purpose bank account of the trust. The sponsors will provide some 'seed money' in the account. Bangladesh Bank (the central bank of Bangladesh) can act as the lead sponsor and few reputed financial institutions can also contribute. Than it needs to register as a public limited company. The board of trustee will work as the board of governor of the company. The board of governor will appoint the CEO or fund manager and top executive to run the company. The company may invest its own projects (at the long term) as well as other PPP projects of various SPVs. The company then applies to the Securities and Exchange Commission (SEC) for enlisting in the capital markets. Then the company will officially invite subscriptions from NRBs through floating shares of the fund.

3.2 Modes of Participation in the Fund: The NRBs will subscribe to the shares of the fund by the following modes.

a) Subscription through local account: A NRB can apply directly, by enclosing a foreign currency demand draft drawn on a bank payable at Dhaka, or through a nominee (including a Bank or a Company) by paying from foreign currency deposit account maintained in Bangladesh. The value of securities may be paid in Taka, US Dollar or UK Pound Sterling at the rate of exchange mentioned on the application form. Refund against over subscription shall be made in the currency in which the applicant paid the value of shares. The same could be reversed for withdrawing the investment.

b) Subscription through foreign currency account: Bangladesh government can open some foreign accounts in countries from where it receives majority of remittances, like KSA, UAE, UK, USA etc., for facilitating the NRBs to subscribe into the infrastructure fund. Money from these accounts would be channeled into the fund at company's disposal.

c) The way of exiting from the fund: NRBs can exit from the fund by off-loading their shares in the stock market. This infrastructure fund will be listed in Bangladeshi stock markets. It can also be listed in other stock exchanges of some major countries like 
KSA, UAE, UK, USA, etc., from where most of remittances come. This will give NRBs an easy option to sell their shares and withdraw the investments.

3.4 Mode of Investment by the Fund: The company makes investments with the pooled money after assessing potentially viable infrastructure projects. Based on the project selection and modes of investment, it will help to add value to this fund. This fund could be invested in two ways: equity and debt. Equity involvement could come in two forms:

i. Direct equity: The fund can take part in the direct equity form when a project company is awarded with the contract of building, operating or any form of the private infrastructure projects. It can also act as sponsor (equity holder) or subordinate sponsor during the submission of the bid documents to get the contract.

ii. Pre-IPO private placement: A company offers private placement scheme to institutional sponsors before floating IPOs to increase the credibility of the incumbent IPO. This incurs less cost for the company as it does not need any floatation or underwriting cost and it increases the credibility of the incumbent Initial Public Offering (IPO). The company can subscribe to this option of equity participation after analyzing all the critical issues of a company's financial strength. This share can easily be off-loaded once the company is listed in the stock exchange.

Debt involvement also comes in two forms:

i. Direct Debt: It is a direct participation (non-transferable) by the Infrastructure Fund for financing an infrastructure project and the debt terms which will be negotiated between the company and the lead financier. Generally, the debt portion of a PPP project is covered through banking syndication where a lead financier acts on behalf of the consortium members. This type of financing will enjoy the facilities as a senior lender, but as this is a long-term investment high discretionary measures should be taken from the fund management's point of view.

ii. Funded Debt: It is the long-term debt and the instruments to be used are bonds and debentures (transferable). This is typically repaid in regular amounts over the life of the bonds in equal installments. The issuer of these instruments can buy it back from the holders before the stated maturity date at the call price, which is higher than the par value. This could be good fund diversification tool as it is less risky in nature but provides a guaranteed return. This type of financing will enjoy all the facilities a subordinate lender enjoys in the debt structure.

\subsection{Discussion}

The proposed company will help in channeling the remittances of NRBs for infrastructure development of the country. It has good potentiality to allow the huge amount of remittances to be tagged in a pool of fund which can be utilized in infrastructure development of the country. Generally NRBs invest through channels of family of social relationships in discrete investments. While they invest in the fund, it has to ensure the comfort to them with investment in a professionally managed fund. The operation of the fund will need to be supervised by the national institutions like Board of Investment. 
The share price of the infrastructure fund depends on the underlying portfolio of assets. So, it needs to be more careful about the investment. Finding good project is also a big challenge. Infrastructure Funds has to access investments that would normally be unavailable to retail investors. The underlying assets also have limited competition so that the assets need to judge carefully, which will provide a sustainable competitive advantage. Essential infrastructures such as airports, roads and docks are crucial to a modern society and have very high replacement costs. So, minimizing the volatility of funds investing in these assets needs to ensure for stable earnings.

At present, there is only two infrastructure company (IIDFC and IDLC) listed in Dhaka Stock Exchange (DSE). So, more infrastructure projects need to be generated and listed in the stock exchange for the proper utilization of the fund. This fund may face the problem of keeping idle money to its disposal due to the scarcity of public infrastructure projects, and a provision should be there to invest this idle money in other private infrastructure projects and profitable sectors as well.

\subsection{Conclusion}

The reason for success with private infrastructure business or PPP is that it is a more secured business with generally guaranteed stream of revenue. Example can be given for Independent Power Producer (IPPs) with defined power purchase agreement. On the other hand, the basic fundamental for the utility of PPP project is that a PPP generally generates lower level of competition as this was generally a government monopoly. The special purpose vehicle who is awarded a PPP project thus enjoys the benefit of doing an infrastructure business that generally has got huge market potential and certain stream of revenue over a long period of time. A PPP business by its vary nature is attractive for private sector investors as realized through the number of bids submitted by interested bidders in the tender process for a PPP project.

For this purpose, NRB Infrastructure Fund is highly desired for financing infrastructure projects in Bangladesh. The fund will pool money from NRBs by floating shares to NRBs with a size in the range more than US $\$ 1$ billion per year. It can be formed as a trust leading to a public limited company where the board of trustee may be selected from renowned personalities of Bangladesh or NRB. Bangladesh Bank can be the lead sponsor of the fund with some seed money followed by other institutional sponsors, which will encourage NRBs to participate in the fund. This fund will be managed by a professional fund manager or executive body of the company, who makes investment decisions. The activities of the company will be monitored by the board of trustees.

The Fund will be invested in various infrastructure projects that will basically work to reduce the deficiency of overall country infrastructure gap and also to ensure proper return for the NRBs. So, the structure of the fund or the company is a very crucial issue for its success. As NRB is the main key stakeholder, before forming the fund officially, government should take the concern of NRBs regarding several legal and administrative frameworks.

\section{References}

Bangladesh Bank. 2006. Bangladesh Bank Bulletin, Money and Banking, pp 22, JulySeptember. 
Berlage, L., Havet, K., Leman, J. and Soenen, H. 2003. Transfers van migranten: omvang en effecten. VLIR, Brussel/KULeuven, Leuven.

BPSIG, 2004. Bangladesh Private Sector Infrastructure Guideline, Government of Bangladesh, Sce-3.11, pp. 6620, October.

DSE. 2010. Dhaka Stock Exchange, 10 June. Available at <www.dsebd.com>

INAFI. 2004. Harnessing Remittances for Economic Development in Bangladesh. International Network of Alternative Financial Institutions, Philippines.

Kuddus, U. M. 2003. Channeling Diaspora Remittance into the Securities Market of Bangladesh. Internship report for IOM. Institute of Business Administration, University of Dhaka, Dhaka.

Siddiqui, T. 2003. Migration as a livelihood strategy of the poor: the Bangladesh case. Dhaka: Refugee and Migratory Movements Research Unit, Dhaka University. Available at <http://www.livelihoods.org/hot_topics/docs/Dhaka_CP_5.pdf>

The Daily Star. 2002. Remittance marks 20.5pc growth during July-Nov. 4 January. Available <http://www.smc.org.ph/amnews/amn020715/southasia/bangladesh020715.htm>

The Daily Star. 2004. Remittance witnesses growth on contribution from expats in KSAFlow declines from Malaysia, Kuwait, Bahrain. 25 July. Available at <http://www.thedailystar.net/2004/07/25/d40725050147.htm>

The Daily Star. 2010. 2009 remittance sets new benchmark. 5 January. Available at $<2009$ remittance sets new benchmark>

World Bank. 2005. Global economic prospects 2006: economic implications of remittances and migration, page 92, World Bank, November 2005.

\footnotetext{
${ }^{1}$ Non-Resident Foreign Currency Deposit (NFCD): This deposit account can be opened any bank operating in Bangladesh. The account can be opened for one month, three months, six months or one-year term in foreign currency i.e. US Dollar, Pound Starling, and Euro etc. The minimum deposit requirement is US $\$ 1000$ or 500 pound starling or equivalent to other currency.

${ }^{2}$ US Dollar Premium Bond: The Bond is issued for three years in the name of a holder of a non-resident account against remittances from abroad to the account. The Bondholder will be entitled to draw interest on half yearly basis at $7.5 \%$ fixed rate per annum in Bangladesh currency at the USD/BDT rate. However the Bondholder may surrender the Bond before maturity and encash the same at the paying office in which case lower interest will be paid.

${ }^{3}$ Wage Earners Development Bond: Bangladeshi wage earners serving abroad and sending remittance in the country are entitled to purchase this bond. The Bond will mature for payment on or after five years from the date of its purchase and the annual interest rate is $12 \%$. But the Bondholder may surrender the Bond and encash the same at the paying office after six months of purchase when he will be paid the principal amount together with interest on premature encashment rate.
} 